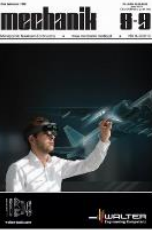

Authors: Jan Burek, Artur Szajna, Tomasz Rydzak

Title of article: „Wpływ kąta pochylenia osi trzpieniowej diamentowej ściernicy kulistej na chropowatość powierzchni” ("Influence of the tilt angle of an spherical diamond head for roughness parameters")

Mechanik, Vol. 91, No. 8-9 (2018): pages 706-708

DOI: https://doi.org/10.17814/mechanik.2018.8-9.111

\title{
Influence of the tilt angle of an spherical diamond head for roughness parameters
}

\section{Wpływ kąta pochylenia osi trzpieniowej diamentowej ściernicy kulistej na chropowatość powierzchni}

\author{
JAN BUREK \\ ARTUR SZAJNA \\ TOMASZ RYDZAK *
}

The article presents the results of experimental research for grinding of corundum ceramic with the use of an spherical diamond head. Article shows the influence of tilt angle and feed on roughness parameters. Authors also described influence of tilt angle and thickness of the grinding layer on effective cutting speed.

KEYWORDS: grinding, corundum ceramics, spherical diamond head, tilt angle of spherical diamond head

In recent years, there has been a clear increase in the demand for elements made of corundum ceramics with complex geometry. This applies to parts used both in the tool industry and in medical engineering - for elements of bone, joint or tooth implants [1-3].

Currently used machining technologies allow to perform these complex geometrical structures on five-axis milling centers made of metal materials and - to a very limited extent - from ceramic materials (in principle this applies only to the green state, after isostatic pressing) [2]. The shaping of elements with complex geometry from sintered corundum and zirconium ceramics takes place only on multi-axis machining centers in the process of diamond grinding, spindle grinding wheels with small diameters - on the order of a few millimeters $[4,6]$. The use of such small tools requires high speeds of the tool spindle in order to achieve the right grinding speed. Achieved grinding speeds are usually around $5 \mathrm{~m} / \mathrm{s}$.

The kinematics of such a five-axis grinding process with spherical grinding wheels is shown in fig. 1. In this process, the grinding spindle axis orientation should be appropriately changed in order to obtain the grinding speed $v_{\mathrm{c}}$. This applies both to the angle of tilt of the grinding wheel axis $\beta$ (in the $Z Y$ plane) as well as the angle of advance $\alpha$ (in the $Z X$ plane). Depending on the change of the tilt angle of the grinding wheel axis $\beta$, the effective diameter of the grinding wheel changes (contact of the grinding wheel working surface with the machined surface) (fig. 2).

\footnotetext{
* Dr hab. inż Jan Burek, prof. PRz (jburek@prz.edu.pl); mgr inż. Artur Szajna (a.szajna@prz.edu.pl); mgr inż. Tomasz Rydzak (t.rydzak@prz. edu.pl) - Katedra Technik Wytwarzania i Automatyzacji, Wydział Budowy Maszyn i Lotnictwa Politechniki Rzeszowskiej
}

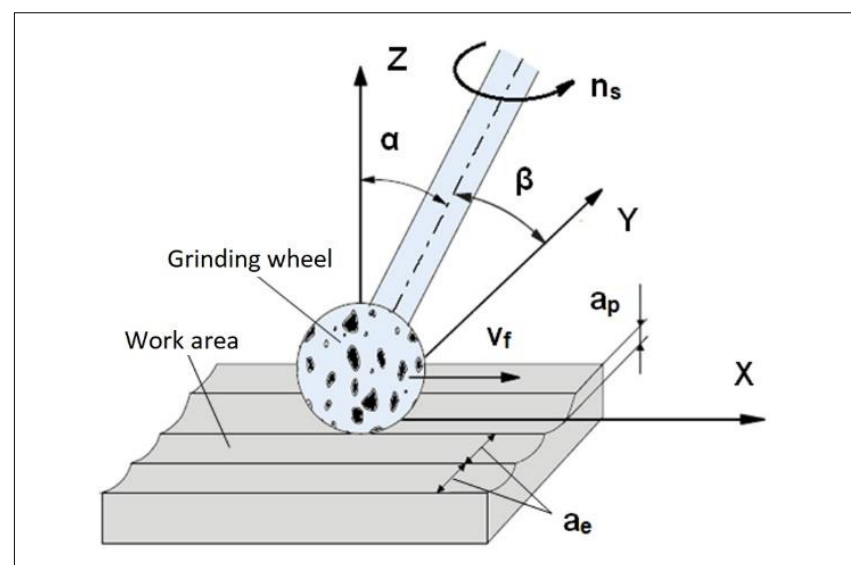

Fig. 1. Orientation of the grinding wheel position angles $\left(a_{p}\right.$ - grinding depth, $a_{\mathrm{e}}$ - grinding width, $\alpha$ - lead angle, $\beta$ - tilt angle, $n_{\mathrm{s}}$ - grinding wheel rotation speed) [1]

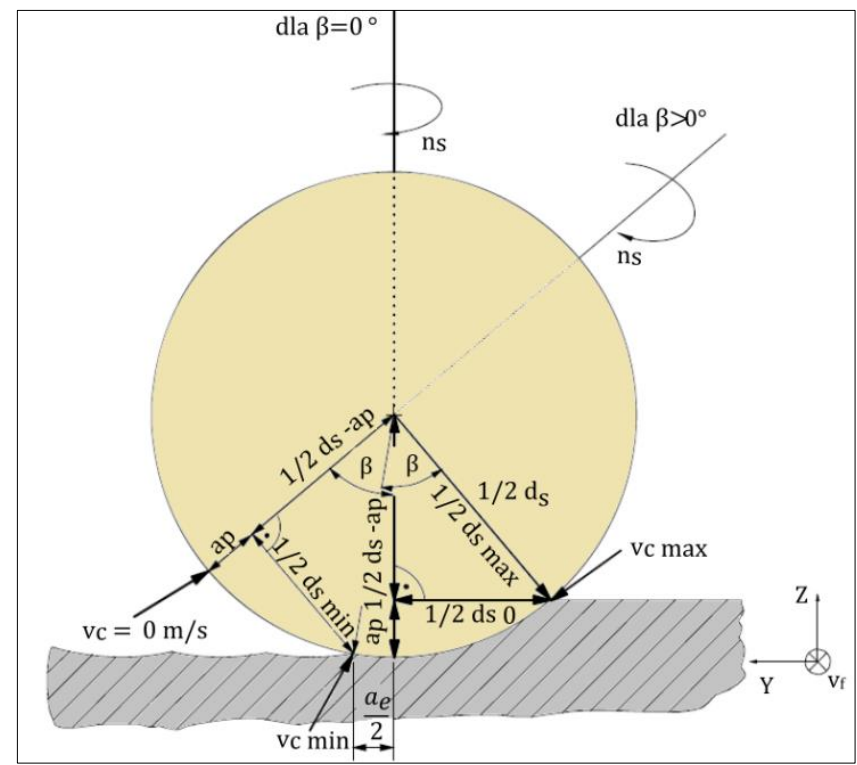

Fig. 2. Influence of the tilt angle $\beta$ of the grinding wheel axis on the change of the effective diameter of the grinding wheel [5] 
Values of the minimum and maximum effective cutting speed $v_{\mathrm{c} \min }$ and $v_{\mathrm{c} \max }$ at the angle of advance $\alpha=0^{\circ}$ and variable angle of tilt $\beta$ assume values resulting from the following relationships:

$$
\begin{aligned}
& V_{\mathrm{c} \min }=\frac{\pi \cdot d_{\mathrm{s} \min } \cdot n_{\mathrm{s}}}{60000}[\mathrm{~m} / \mathrm{s}] \\
& V_{\mathrm{c} \max }=\frac{\pi \cdot d_{\mathrm{smax}} \cdot n_{\mathrm{s}}}{60000}[\mathrm{~m} / \mathrm{s}]
\end{aligned}
$$

where: $n_{\mathrm{s}}-$ wheel rotation speed, $d_{\mathrm{s} \text { min }}-$ minimum effective wheel diameter, $d_{\mathrm{s} \text { max }}-$ maximum effective wheel diameter.

Due to the change in the effective contact diameter of the grinding wheel, the effective cutting speed $v_{c}$ also changes.

The following parameters were adopted for the analysis of the influence of the angle of tilt of the wiper shaft axis on the effective cutting speed value:

- wheel diameter $d_{\mathrm{s}}=4.4 \mathrm{~mm}$,

- rotation speed of the grinding wheel $n_{\mathrm{s}}=25,000 \mathrm{rev} / \mathrm{min}$,

- cutting depth $a_{p}=30 \mu \mathrm{m}$,

- cutting width $a_{\mathrm{e}}$ depending on the theoretical roughness, $R t=0.5 \mu \mathrm{m}$, according to the following formula:

$$
R_{\mathrm{t}}=\frac{d_{\mathrm{s}}}{2}-\sqrt{\left(\frac{d_{\mathrm{s}}}{2}\right)^{2}-\left(\frac{a_{\mathrm{e}}}{2}\right)^{2}}[\mu \mathrm{m}]
$$

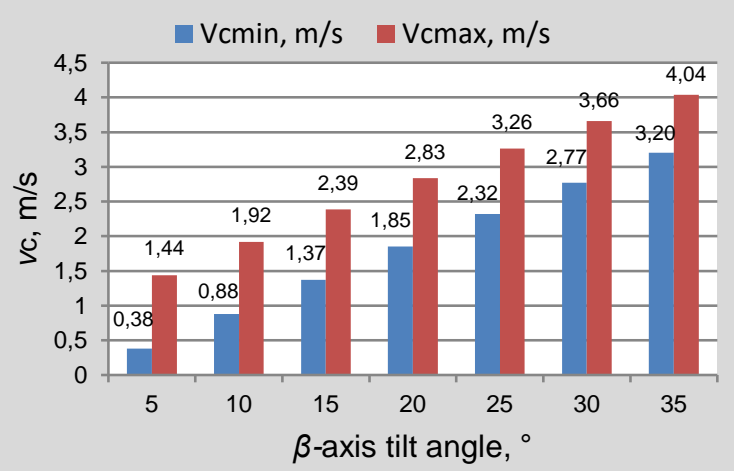

Fig. 3. The values of the effective cutting speed obtained for the Dremel 7105 grinding wheel with a variable tilt angle $\beta$ of the tool axis

It was noted that for small values of the angle $\beta$ the difference between the maximum and the minimum effective cutting speed is significant (fig. 3). As the value of the $\beta$ angle increases, the difference decreases. For the angle $\beta=5^{\circ}$ the ratio $v_{\text {cmax }} / v_{\text {cmin }}$ is equal to 3.79 , and for $\beta=35^{\circ}$ it is 1.26 .

\section{Research stand and test conditions}

The study of the corundum ceramics grinding process was carried out on a five-axis Sauer machining center (fig. 4) with the Sinumerik 840 D control system.
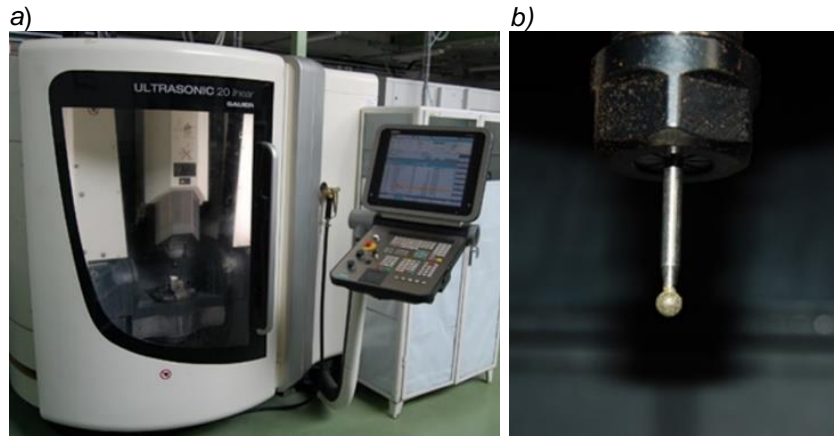

Fig. 4. Test stand: a) machine tool, b) grinding wheel Dremel 7105
The treatment was carried out using a galvanized, diamond coated grinding wheel 7105 from Dremel. Nominal diameter of the grinding wheel $d_{s}=4.4 \mathrm{~mm}$. The grinding tests were carried out on a pre-baked corundum frame. The purpose of these tests was to determine the influence of the tilt angle $\beta$ of the grinding wheel axis on the roughness parameters $R a$ and $R z$ at different values of feed speed $v_{\text {t }}$.

Three identical pro-walled samples were prepared for the grinding tests, divided into seven equal parts (zones) on the end face (fig. 5).

Fig. 5.

Division of the sample into grinding zones

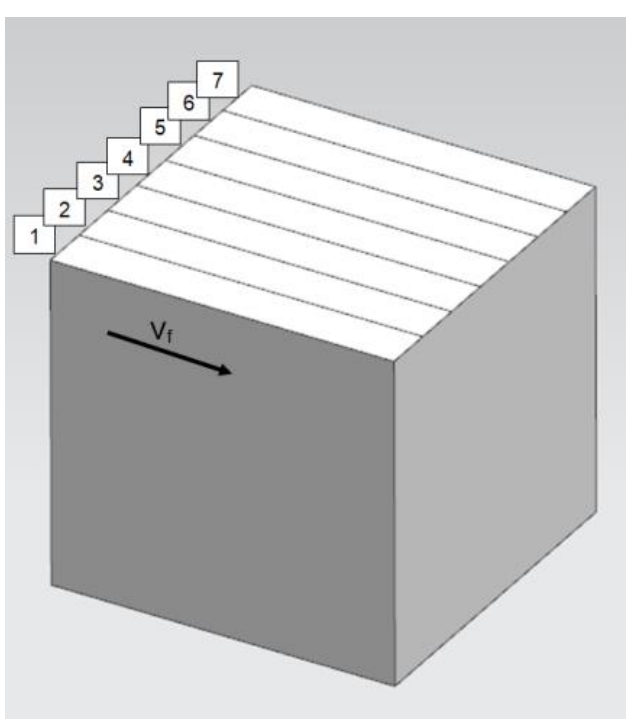

The samples were ground at different feed rates and with a constant grinding depth ap. In each zone, different values of the angle of tilt of the axis of the grinding wheel $\beta$ have been adopted (tab. I)

TABLE I. Values of the tilt angles $\beta$ between the zones machining

\begin{tabular}{|c|c|c|c|c|c|c|c|}
\hline Zone number & 1 & 2 & 3 & 4 & 5 & 6 & 7 \\
\hline Angle value $\beta,^{\circ}$ & 5 & 10 & 15 & 20 & 25 & 30 & 35 \\
\hline
\end{tabular}

The following parameters were used in the grinding process:

- rotation speed of the grinding wheel $n_{\mathrm{s}}=25,000 \mathrm{rev} / \mathrm{min}$,

- cutting depth $a_{p}=30 \mu \mathrm{m}$,

- tilt angle of the grinding wheel axis $\beta=5^{\circ}, 10^{\circ}, 15^{\circ}, 20^{\circ}$, $25^{\circ}, 30^{\circ}, 35^{\circ}-$ depending on the work zone (tab. I),

- lead angle $\alpha=0^{\circ}$ - for each machining zone,

- feed $v_{f}=200,600$ and $1000 \mathrm{~mm} / \mathrm{min}$,

- cutting width $a_{\mathrm{e}}$ - programmed so that the value of the theoretical roughness $R t$ parameter does not exceed $0.5 \mu \mathrm{m}$.

The division of samples into machining zones (fig. 5) and the machining program containing the mentioned parameters were obtained in the NX 11.0 program.

\section{Surface roughness measurement}

The surface roughness measurement after grinding was carried out on the Mahr MarSurf GD profile. The measuring head MFW-250: 1 (\#6851855) was used for the measurements.

\section{Test results}

The values of $R a$ and $R z$ parameters of surface roughness in individual treatment zones, obtained for different angles $\beta$ and feedrate $v_{\mathrm{f}}$, are shown in tab. II and tab. III as well as in fig. 6 and fig. 7. 
TABLE II. Ra roughness parameter values

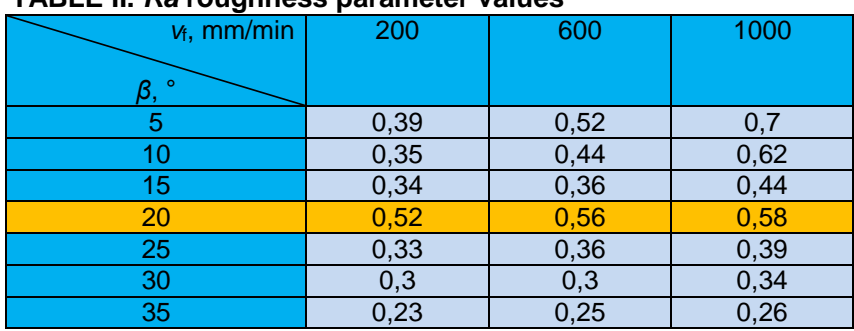

TABLE III. $R z$ roughness parameter values

\begin{tabular}{|c|c|c|c|}
\hline$\beta^{\circ}, \mathrm{mm} / \mathrm{min}$ & 200 & 600 & 1000 \\
\hline 5 & & & \\
\hline 10 & 2,93 & 3,59 & 4,67 \\
\hline 15 & 2,78 & 3,26 & 3,86 \\
\hline 20 & 1,98 & 1,87 & 2,98 \\
\hline 25 & 3,05 & 3,66 & 3,79 \\
\hline 30 & 2,18 & 2,53 & 2,63 \\
\hline 35 & 1,84 & 2,28 & 2,23 \\
\hline & 1,66 & 1,8 & 1,83 \\
\hline
\end{tabular}

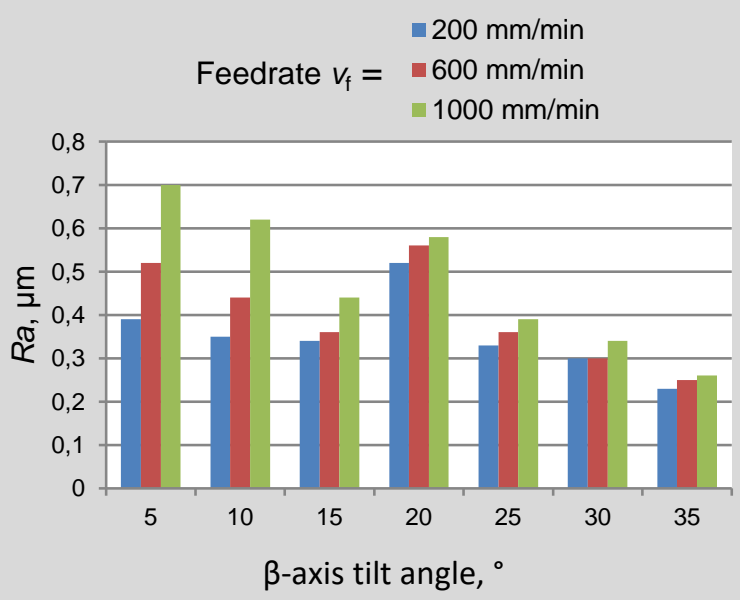

Fig. 6. Ra surface roughness parameter values obtained with variable values of angle $\beta$ and different feed values $v_{f}$

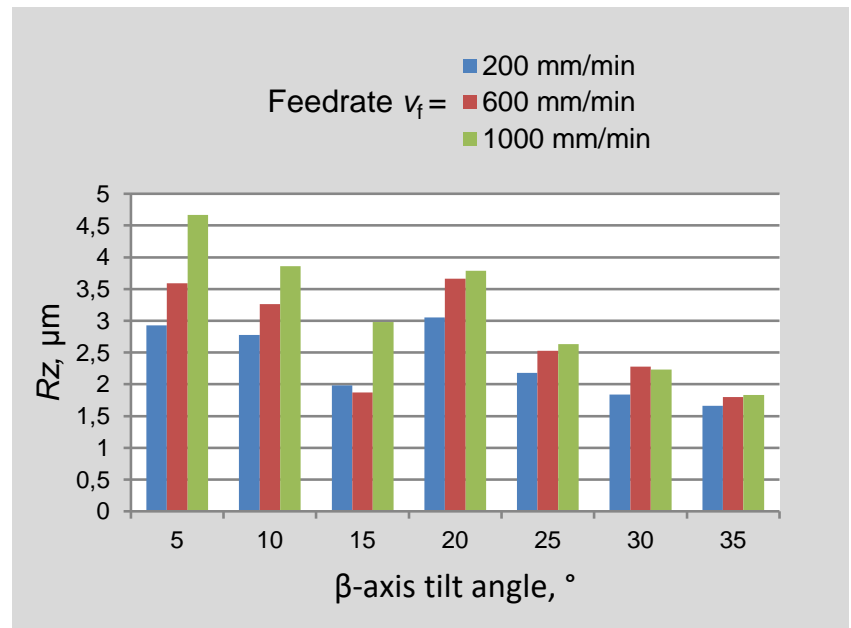

Fig. 7. Surface roughness parameters values obtained at variable values of angle $\beta$ and different feed values $v_{f}$

The presented results of roughness parameters $R a$ and $R z$ measurements indicate that the value of the tilt angle of the $\beta$ axis has a significant influence on the obtained surface roughness. The smaller the value of this angle, the greater the surface roughness. With the increase of the $\beta$-angle, an improvement in the $R a$ and $R z$ parameters was observed.

Corresponding to the increase in the feed speed vf, the $R a$ and $R z$ roughness parameters also increased (fig. 6 and fig. 7). The slope angle $\beta=20^{\circ}$ was characteristic. For this value there was a significant increase in the $R a$ and $R z$ roughness (fig. 6 and fig. 7). The smallest values of $R a$ and $R z$ parameters were obtained with the highest value of $\beta$ angle and the smallest feed value $v_{f}$. The setting of the high value of the angle $\beta$ with the high velocity $v_{f}$ gave similar effects to the previously discussed parameter combination.

It was also observed that with the increase of the $\beta$ angle, the influence of feed on the roughness of the surface being treated decreases.

Considering all the results obtained, it was found that in order to obtain the best in terms of $R a$ and $R z$ parameters, the surface roughness and to ensure adequate machining efficiency, the greatest possible values of the tilt angle $\beta$ and the accompanying high feed rates should be used.

\section{Conclusions}

The tests show that the roughness of the surface to be machined largely depends on the effective cutting speed, which in turn is significantly conditioned by changes in the angle of tilt of the axis of the abrasive $\beta$. The value of the feedrate $v_{f}$ is also significant, which causes a clear change in the roughness parameters $R a$ and $R z$, especially in the case of small values of the angle $\beta$. With the increase of the angle $\beta$, the influence of feed on the roughness of the surface being treated decreases.

The next step in the process of grinding the corundum complex with the mandrel spherical grinding wheel should be the analysis of the influence of angles controlling the position of the tool relative to the surface to be machined on selected parameters of the geometric structure of the surface for different material sintering stages. An important issue is also the verification of phenomena causing a sudden increase in the values of $R a$ and $R z$ parameters for the angle $\beta=20^{\circ}$.

\section{REFERENCES}

1. Burek J., Szajna A., Lisowicz J., Rydzak T. „Dokładność i chropowatość powierzchni po pięcioosiowym szlifowaniu ściernicą kulistą". Mechanik. 8-9 (2017): pp. 763-765.

2. Habrat W., Wdowik R., Porzycki J., Świder J. „Określenie granicznych wartości porowatości pozornej ceramiki korundowej i cyrkonowej w stanie białym dla potrzeb obróbki ściernicami z mikrokrystalicznego korundu spiekanego". Mechanik. 8-9 (2014): pp. 143-146.

3. Koprowski J., Uhlmann E., Weingaertner W. "Influence of tilt and lead andles on 5-axis grinding with spherical mounted points". Springer, 2018, pp. 11740-11746.

4. Marinescu I.D. "Handbook of Advanced Ceramics Machining". CRC Press Taylor \& Francis Group, 2007, pp. 327-353.

5. Schmidt Ch. "Koordinatenschleifen dentalkeramischer Werkstoffe mit kleinen Diamantwerkzeugen". Aachen: Shaker, 2008.

6. Uhlmann E., Koprowski S., Weingaertner W., Rolon D.A "Modelling and simulation of grinding processes witch mounted points: Part II of II - Fast modeling method for workpiece surface prediction". Procedia CIRP. 46 (2016): pp. 603-606. -

Translation of scientific articles, their computer composition and publishing them on the website www.mechanik.media.pl by original articles in Polish is a task financed from the funds of the Ministry of Science and Higher Education designated for dissemination of science.
Ministry of Science and Higher Education Republic of Poland 